\title{
The population structure of two sympatric hermit-crab species on a subtidal rocky shore of an island in southeastern Brazil
}

\author{
DANIEL J.M. LIMA ${ }^{1,2,3}$, VALTER J. COBO ${ }^{2,3}$, MARIANA A.B. DE AQUINO ${ }^{2,3}$ and ADILSON FRANSOZO ${ }^{1,2}$ \\ ${ }^{1}$ Universidade Estadual Paulista/UNESP, Departamento de Zoologia, Instituto de Biociências, \\ Distrito de Rubião Junior, s/n, 18618-970 Botucatu, SP, Brasil \\ ${ }^{2}$ NEBECC, Núcleo de Estudos em Biologia, Ecologia e Cultivo de Crustáceos, Departamento de Zoologia, \\ Instituto de Biociências, Distrito de Rubião Júnior, s/n, 18618-970 Botucatu, SP, Brasil \\ ${ }^{3}$ Laboratório de Biologia Marinha/LabBMar, Instituto Básico de Biociências de Taubaté/UNITAU, \\ Av. Tiradentes, 500, Centro, 12030-180 Taubaté, SP, Brasil
}

Manuscript received November 26, 2013; accepted for publication on May 5, 2014

\begin{abstract}
The main goal of this investigation was to characterize the population structure and shell occupancy of two sympatric hermit-crab species, Pagurus brevidactylus and Paguristes tortugae. The study was undertaken at Couves Island on the southeastern coast of Brazil, from March 2010 through February 2011, on subtidal rocky bottoms. Specimens were collected by SCUBA diving sessions. A total of 195 individuals of $P$. brevidactylus and 132 of $P$. tortugae were examined. Both populations showed unimodal size-frequency distributions, which were non-normal for $P$. brevidactylus and normal for P. tortugae. The median size of $P$. brevidactylus was significantly smaller than $P$. tortugae; in both species, males were significantly larger than females. For both, juveniles and ovigerous females were recorded in all size classes and in almost the entire sampling period. No significant departures from the 1:1 sex ratio were detected, although some size classes were skewed. Overlaps in shell occupation were recorded. Pagurus brevidactylus and P. tortugae showed similar population features; they reached sexual maturity at small sizes, and the nearly year-round presence of young and ovigerous females suggests continuous reproduction. These inter-specific interactions involving resource partitioning suggest a regulatory process that is probably part of the equilibrium strategy of these populations.
\end{abstract}

Key words: continuous reproduction, rocky bottoms, shell partitioning, sympatric species.

\section{INTRODUCTION}

The hermit crabs Pagurus brevidactylus and Paguristes tortugae are widely distributed along the southwestern Atlantic coast, where they are dominant and sympatric on rocky bottoms (Mantelatto and Garcia 2002). Both species occur in the subtidal zone of continental islands along the southeastern Brazilian coast (Melo 1999).

Correspondence to: Daniel José Marcondes Lima

E-mail: daniellima@ibb.unesp.br
Mantelatto and Sousa (2000) and Mantelatto et al. (2005) noted that the pagurid P. brevidactylus and the diogenid $P$. tortugae are small species compared to other hermit crabs in the same area (e.g., Dardanus insignis, Paguristes erythrops, Petrochirus diogenes). Both species are common in the western Atlantic, distributed from North Carolina and Florida, USA, for P. tortugae and P. brevidactylus respectively, to the state of Santa Catarina, Brazil. Usually, they are found on rocky 
and sandy bottoms and in algae beds, from shallow water to approximately $50 \mathrm{~m}$ deep (Melo 1999, Nucci and Melo 2007).

Several features and properties such as density, recruitment and growth determine the dynamics of natural populations (Hutchinson 1981). These properties may change as a function of population size and over spatial and temporal scales, even in simple communities, and are caused by inter- and intraspecific relationships and variations in environmental factors such as photoperiod, temperature and precipitation (Thorson 1950, Begon et al. 2007).

Most tropical and subtropical decapod species show continuous reproduction, usually associated with warm waters and availability of food for planktonic larvae (Orton 1920, Thorson 1950). For hermit crabs, Bertness (1981) suggested that the reproductive pattern of a population is closely related to shell availability, as a function of intraspecies competition. According to Spight (1977), the composition of a hermit-crab community is strongly influenced by shell availability, in that coexisting species compete for the most suitable shells, with the dominant species holding the best ones and the subordinate species occupying the less-suitable shells. Occupation of an unsuitable shell is highly stressful for crabs (Chase et al. 1988, Turra and Leite 2001, 2004).

Southeastern Brazilian coastal waters are highly impacted by anthropogenic activities, especially in areas with high potential for exploitation of hydrocarbon fuels, such as the Santos Basin, the Draft Gas Exploration of Mexilhões Field, and the expansion of São Sebastião Harbor (Rocha et al. 2010). Considering the recent intensification of which pressures, especially oil spills, prior knowledge of the population structure of some representative species, and how they interact, could be an important baseline for assessing environmental damage.

Since $P$. brevidactylus and $P$. tortugae dominate in subtidal rocky-bottom communities, this investigation characterized the population structure and the shell occupancy pattern for these two hermitcrab species of the southeastern Brazilian coast.

\section{MATERIALS AND METHODS}

The study was conducted at Couves Island (2325'15'S-4451'39'W) (Fig. 1), southeastern coast of Brazil. Hermit crabs were collected monthly from March 2010 through February 2011, on subtidal rocky bottoms, at depths of 5-10 m. Specimens were caught in daytime, during SCUBA diving sessions, with a sampling effort of $1 \mathrm{~h} / \mathrm{mo}$. The crabs were collected by hand in a quadrat of $20 \mathrm{~m}^{2}(2 \mathrm{~m} \mathrm{x} 10 \mathrm{~m})$, sited monthly and randomly on the subtidal rocky bottoms, in the protected portion of Couves Island. The specimens were stored in plastic bags, frozen, and transferred to the Zoology Laboratory at the University of Taubaté. Each month, bottom-water temperature was measured with a thermometer coupled to a dive computer, and salinity was measured by means of an optical refractometer.

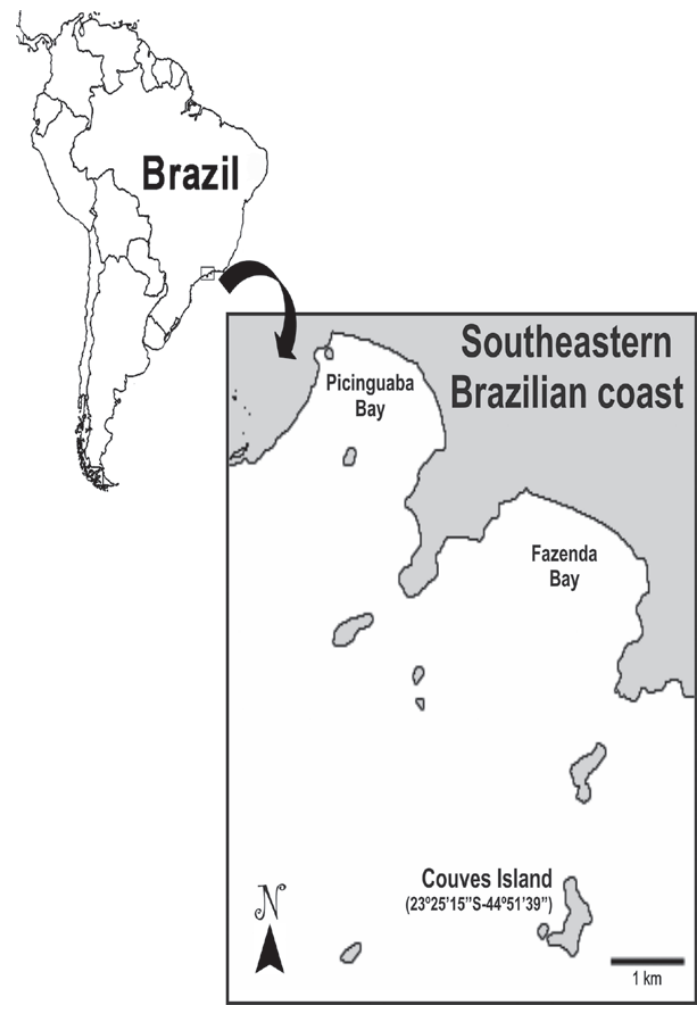

Figure 1 - Map of Brazil, southeastern Brazilian coast, with indication of Couves Island, Ubatuba (SP), Brazil. 
Shell species were identified according to Rios (1994), and in some cases with the help of specialists. Shell aperture length (SAL), width (SAW) and dry weight (SDW) were measured. Shells were cracked in order to carefully remove the hermit crabs, measured for cephalothoracic shield length (CSL $=$ from the tip of the rostrum to the groove at the posterior edge) and weighed (WW = wet weight). Measurements were made with a caliper (nearest $0.1 \mathrm{~mm}$ ) under a stereoscopic microscope. The relationships between hermit-crab size and the shell variables were evaluated by regression analysis.

Specimens of both species were sexed by the number of pleopods, i.e., four unpaired abdominal appendages for females and three pleopods on the left side for males, as well as the gonopore position, on the $5^{\text {th }}$ and $3^{\text {rd }}$ pairs of pereopods for females and males, respectively. Ovigerous females were those who carried eggs on the pleopods. Reproductive activity was estimated as the monthly proportion of ovigerous females to the total number of adult females.

Hermit crabs were allocated to size classes and grouped into five demographic categories: juvenile males (JM), adult males (AM), juvenile females (JF), adult females (AF), and ovigerous females (OF). Individuals of both sexes who were smaller than the smallest ovigerous female were classified as juveniles.

The normal distribution of the population was verified by the Shapiro-Wilk test $(a=0.05)$. The Mann-Whitney Sum test (U) was applied to compare the median size of the demographic categories $(a=$ 0.05). The median shell aperture length (SAL) was compared using the Mann-Whitney Sum test (U) and the Kruskal-Wallis test $(\mathrm{H})$. The sex ratio was estimated as the quotient between the frequency of males and the total number of individuals in the samples. Each monthly sample was tested for deviations from the 1:1 sex ratio with the Binomial test $(a=0.05)$ (Wilson and Hardy 2002). Spearman correlation (rs) $(a=0.05)$ was used to test significant relationships between water temperature and salinity, and the absolute abundance of individuals for both crab species. The preference for shell type was estimated by the percentage of occupation of the chosen species, and the Chi-square test $\left(X^{2}\right)$ was used to compare occupancy rates of shells of the different gastropod species.

\section{RESULTS}

A total of 195 individuals of Pagurus brevidactylus were recorded, consisting of 105 males (12 JM, $93 \mathrm{AM}$ ) and 90 females (7 JF, 24 AF, 59 OF); in addition to 132 Paguristes tortugae, consisting of 59 males (2 JM, $57 \mathrm{AM}$ ) and 73 females ( $1 \mathrm{JF}, 25 \mathrm{AF}, 47 \mathrm{OF}$ ). The crabs were distributed in eight size classes with 0.35 mm CSL intervals, ranging from 0.9-3.7 mm CSL for $P$. brevidactylus; and into nine size classes with $0.70 \mathrm{~mm}$ CSL intervals, ranging from 1.1$7.4 \mathrm{~mm}$ CSL for P. tortugae.

The specimens of $P$. brevidactylus ( $M=$ $2.00 \pm 0.44 \mathrm{~mm}$; range $=1.0-4.0 \mathrm{~mm} \mathrm{CSL}, n=195)$ were significantly smaller than $P$. tortugae $(M=$ 4.10 $\pm 1.40 \mathrm{~mm}$; range $=1.1-7.3 \mathrm{~mm} \mathrm{CSL}, n=132$ ) (Mann-Whitney U test, $U=2323.000, N_{1}=195, N_{2}=$ $132, P<0.01)$. Males were significantly larger than females for both $P$. brevidactylus (Mann-Whitney U test, $\left.U=3868.500, N_{1}=105, N_{2}=90, P<0.05\right)$ and P. tortugae (Mann-Whitney $\mathrm{U}$ test, $U=1506.000$, $\left.N_{l}=59, N_{2}=73, P<0.01\right)$.

The population size-frequency analysis indicated a unimodal and non-normal distribution for $P$. brevidactylus (Shapiro-Wilk test, $W=$ 0.958, $P<0.001$ ), and a unimodal and normal distribution for $P$. tortugae (Shapiro-Wilk test, $W=0.985, P>0.05)$.

For $P$. brevidactylus, juveniles were recorded in the size classes of $0.90-] 1.25$ and $1.25-] 1.60$ $\mathrm{mm}$ CSL. Adults were recorded mainly in the size classes of 1.60 - 11.95 and 1.95 - $] 2.30 \mathrm{~mm} \mathrm{CSL}$, whereas only adult males were recorded for the last three size classes. Ovigerous females were recorded from the $1.25-] 1.60$ to the 2.30 - 2.65 mm CSL size classes (Fig. 2). 


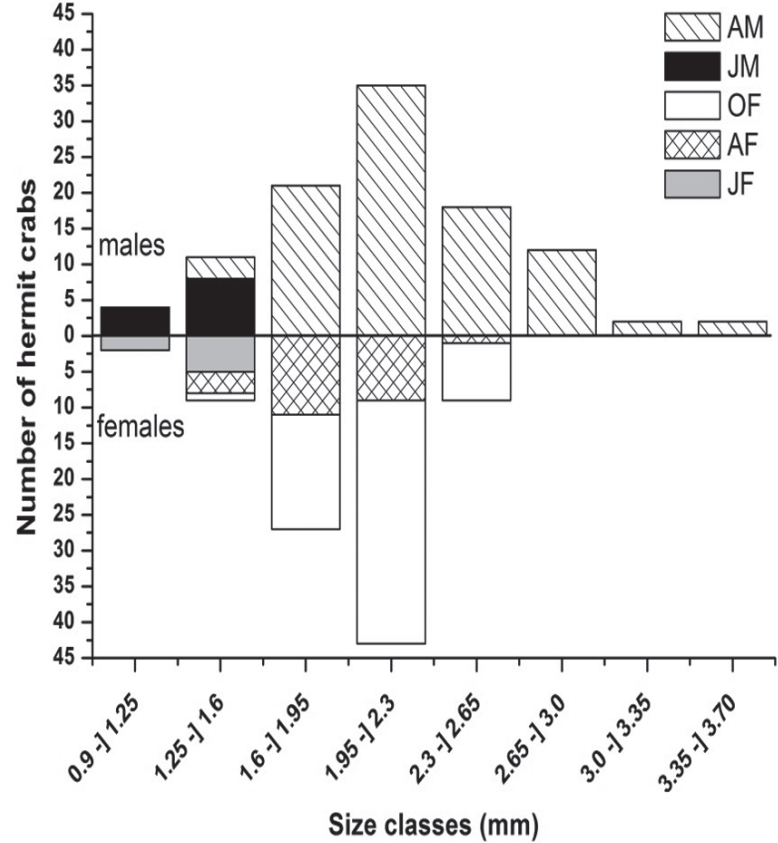

Figure 2 - Absolute frequency by size classes for each demographic category of Pagurus brevidactylus from the subtidal rocky bottom of Couves Island, Ubatuba (SP), Brazil (juvenile males (JM), adult males (AM), juvenile females (JF), adult females (AF) and ovigerous females (OF)).

For $P$. tortugae, juveniles were recorded in the size class of $1.1-] 1.8 \mathrm{~mm}$ CSL, while most adults were in the $3.9-] 4.6 \mathrm{~mm}$ CSL size class. Adult males and ovigerous females were recorded in all size classes, while non-ovigerous females were absent from only the largest size class (Fig. 3).

Juveniles of $P$. brevidactylus were recorded over almost the entire sampling period, except June, September and December 2010 and January 2011, with a main frequency peak in April (51\%). Ovigerous females were absent only during April and June 2010 and January 2011, with the main peak in October 2010 (Fig. 4).

For $P$. tortugae, juveniles occurred only in March and April 2010 and January 2011, with a main peak in March 2010, when they comprised $33 \%$ of the total number of crabs collected during that month. Ovigerous females were recorded throughout the study period except March 2010, with the main peak in October 2010 (Fig. 5).

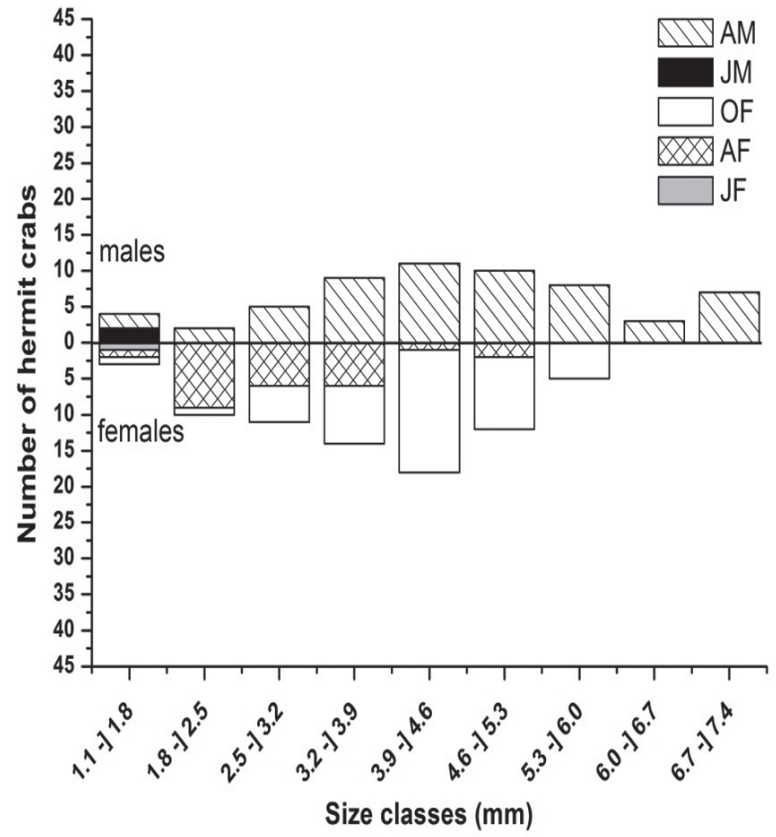

Figure 3 - Absolute frequency by size classes for each demographic category of Paguristes tortugae from the subtidal rocky bottom of Couves Island, Ubatuba (SP), Brazil (juvenile males (JM), adult males (AM), juvenile females (JF), adult females (AF) and ovigerous females (OF)).

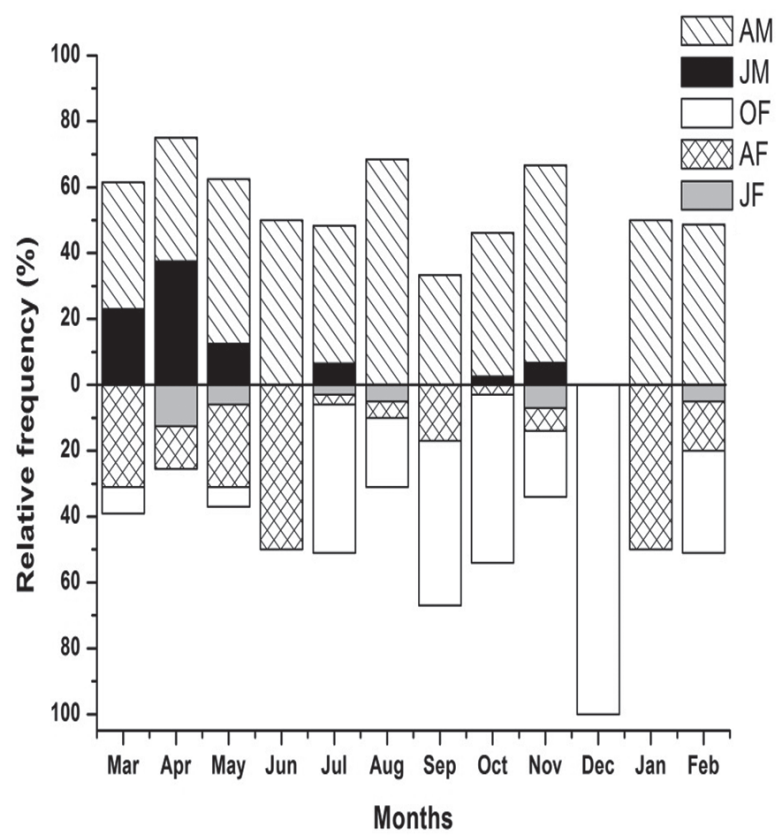

Figure 4 - Monthly relative frequency for Pagurus brevidactylus from the subtidal rocky bottom of Couves Island, Ubatuba (SP), Brazil (juvenile males (JM), adult males (AM), juvenile females (JF), adult females (AF) and ovigerous females (OF)). 


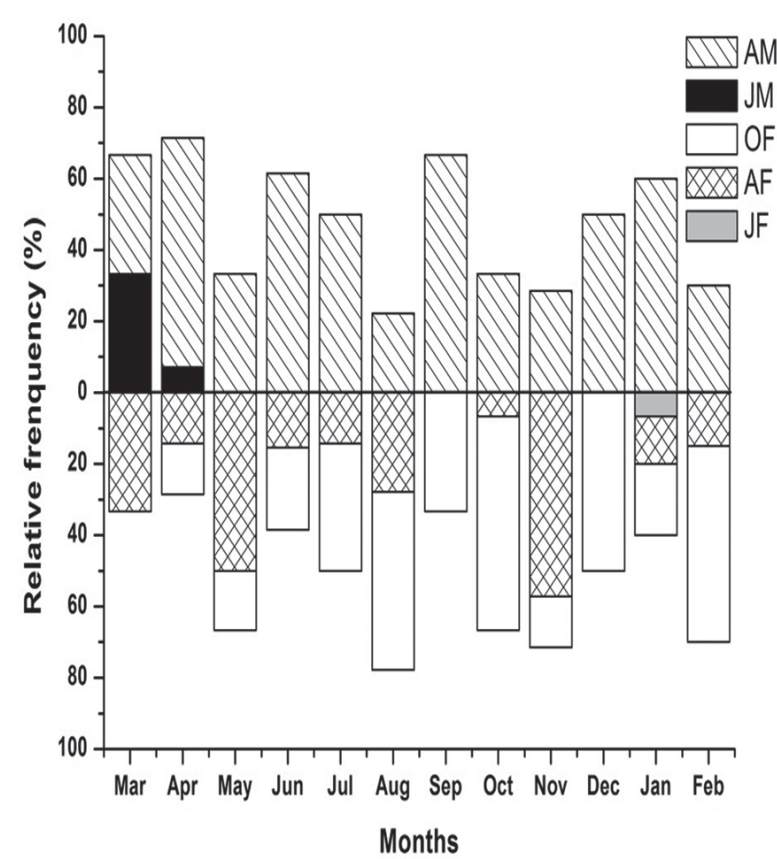

Figure 5 - Monthly relative frequency of Paguristes tortugae from the subtidal rocky bottom of Couves Island, Ubatuba (SP), Brazil (juvenile males (JM), adult males (AM), juvenile females (JF), adult females (AF) and ovigerous females (OF)).

The overall sex ratios recorded during the study period were 1:0.87 $(P>0.05)$ and 1:1.24 $(P>0.05)$ for $P$. brevidactylus and $P$. tortugae respectively, with no significant departures from 1:1 detected for either species. However, some size classes showed skewed sex ratios, for males of $P$. brevidactylus in the size class of $2.3-] 2.65 \mathrm{~mm} \mathrm{CSL}(P<0.05)$, and for $P$. tortugae in the size classes of $1.8-] 2.5 \mathrm{~mm} \mathrm{CSL}(P<0.05)$ and 6.7- $] 7.4 \mathrm{~mm} \mathrm{CSL}(P<0.05)$, biased toward females and males respectively. Only males were present in the two largest size classes for P. tortugae and three largest size classes of $P$. brevidactylus.

Over the sampling period, the bottom-water temperature ranged from $18-29^{\circ} \mathrm{C}(M=22.4 \pm$ $2.9^{\circ} \mathrm{C}$ ), with the lowest temperatures recorded in December 2010 and January 2011, and the highest in October 2010. Salinity ranged from 30 to 36 ( $M=$ $32.3 \pm 2.0$ ), with the lowest salinities in November and December 2010 and January and February 2011, and the highest in May 2010. The salinity levels were negatively associated with the absolute abundance of $P$. tortugae (Spearman test, $\mathrm{rs}=$ $-0.638970, P<0.05)$. Likewise, bottom temperature was not associated with absolute abundance for either P. brevidactylus or P. tortugae.

The hermit crabs occupied shells of 13 gastropod species, with SAL ranging from 1.70 to $22.30 \mathrm{~mm}$, for Cerithium atratum and Cymatium parthenopeum respectively (Table I). Shells of Trachypollia nodulosa, C. atratum and Gemophos auritulus were used most frequently, and together comprised more than $90 \%$ of the shells occupied by both hermit-crab species (Table I). The median SAL did not differ significantly between T. nodulosa and C. atratum (Mann-Whitney U test, $U=3194.500, N_{1}=143, N_{2}=45, P>0.05$ ); however, the median SAL of $G$. auritulus was significantly different from both $T$. nodulosa and C. atratum (Kruskal-Wallis test, $\mathrm{H}=120.44, \mathrm{DF}=$ 2, $\mathrm{N}=245, P<0.01)$.

Pagurus brevidactylus occupied shells of nine gastropod species, particularly T. nodulosa and $C$. atratum, which were used by more than $90 \%$ of the crabs caught. Males used a wider variety of shells than non-ovigerous and ovigerous females, i.e., seven, five and three, respectively. Small specimens between 1.0 and $2.0 \mathrm{~mm}$ CSL occupied mainly shells of $T$. nodulosa, while larger individuals commonly used shells of C. atratum (Table II).

All $P$. brevidactylus demographic categories occupied mainly $T$. nodulosa shells (Chi-square test, $X^{2}=10.7, P<0.01,59 \%$ for males; $X^{2}=3.8, P<0.05$, $62 \%$ for non-ovigerous females; and $X^{2}=36.5, P<$ $0.01,88 \%$ for ovigerous females). Only males and non-ovigerous females were found in shells of $G$. auritulus and Tegula viridula respectively (Table III).

Shells of 11 gastropod species were occupied by $P$. tortugae, particularly $C$. atratum and $G$. auritulus, which together comprised more than 50\% of the shells recorded. Specimens from 1.0 to 3.0 mm CSL used mainly T. nodulosa and C. atratum shells, while most individuals larger than $3.0 \mathrm{~mm}$ CSL occupied G. auritulus shells (Table IV). 
TABLE I

Shell utilization by the two hermit-crab species collected in the subtidal zone of Couves Island ( $N=$ total number of shells occupied; SAL = shield aperture length; SDW = shield dry weight).

\begin{tabular}{|c|c|c|c|c|c|c|}
\hline \multirow{2}{*}{ Gastropod species } & \multicolumn{2}{|c|}{ Total } & \multicolumn{2}{|c|}{ SAL (mm) } & \multicolumn{2}{|c|}{ SDW (mm) } \\
\hline & $\mathbf{N}$ & $\%$ & Range & Median \pm SD & Range & Median \pm SD \\
\hline Cerithium atratum (Born, 1778) & 71 & 21.5 & $1.70-7.0$ & $4.25 \pm 0.92$ & $0.14-1.85$ & $0.90 \pm 0.37$ \\
\hline Trachypollia nodulosa (C.B. Adams, 1845) & 143 & 43.2 & $2.10-6.00$ & $4.29 \pm 0.69$ & $0.23-2.00$ & $0.69 \pm 0.31$ \\
\hline Tegula viridula (Gmelin, 1791) & 2 & 0.6 & $3.50-6.70$ & $5.10 \pm 2.26$ & $1.09-1.50$ & $1.29 \pm 0.29$ \\
\hline Leucozonia nassa (Gmelin, 1791) & 4 & 1.2 & $4.20-7.60$ & $5.82 \pm 1.40$ & $1.12-2.92$ & $1.92 \pm 0.76$ \\
\hline Lithopoma tectum (Lightfoot, 1786) & 12 & 3.6 & $3.70-8.70$ & $6.13 \pm 1.60$ & $0.50-13.40$ & $3.74 \pm 3.73$ \\
\hline Gemophos auritulus (Link, 1807) & 57 & 17.2 & $3.50-19.25$ & $8.12 \pm 2.11$ & $0.26-9.42$ & $3.30 \pm 1.49$ \\
\hline Pisania pusio (Linnaeus, 1758) & 23 & 6.9 & $6.00-11.50$ & $8.46 \pm 1.48$ & $1.00-5.50$ & $3.11 \pm 1.34$ \\
\hline Siratus tenuivaricosus (Dautzenberg, 1927) & 2 & 0.6 & $8.70-15.45$ & $12.07 \pm 4.77$ & $9.84-10.54$ & $10.19 \pm 0.49$ \\
\hline Cymatium parthenopeum (Von Salis, 1793) & 7 & 2.1 & $10.00-22.30$ & $15.53 \pm 4.98$ & $2.80-16.40$ & $8.92 \pm 4.68$ \\
\hline Thais haemastoma (Linnaeus, 1767) & 7 & 2.1 & $5.70-21.50$ & $18.63 \pm 4.72$ & $4.90-15.77$ & $11.03 \pm 3.88$ \\
\hline Modulus modulus (Linnaeus, 1758) & 1 & 0.3 & 3.50 & - & 0.55 & - \\
\hline Coralliophila aberrans (C.B. Adams, 1850) & 1 & 0.3 & 4.50 & - & 0.71 & - \\
\hline Fusinus brasiliensis Grabau, 1904 & 1 & 0.3 & 19.50 & - & 8.90 & - \\
\hline
\end{tabular}

TABLE II

Pagurus brevidactylus. Percentage occupation of gastropod shell species by hermit-crab size classes (Cab Coralliophila aberrans, Cat Cerithium atratum, Gau Gemophos auritulus, Lna Leucozonia nassa, Lte Lithopoma tectum, Mmo Modulus modulus, Ppu Pisania pusio, Tno Trachypollia nodulosa, Tvi Tegula viridula).

\begin{tabular}{|c|c|c|c|c|c|c|c|c|c|}
\hline & Cab & Cat & Gau & Lna & Lte & Mmo & Ppu & Tno & Tvi \\
\hline $1.0-1.3$ & 0 & 20 & 0 & 0 & 0 & 0 & 0 & 80 & 0 \\
\hline $1.3-1.6$ & 0 & 12.5 & 0 & 0 & 0 & 0 & 0 & 87.5 & 0 \\
\hline $1.6-[1.9$ & 0 & 16.3 & 0 & 0 & 2.0 & 0 & 2.0 & 79.6 & 0 \\
\hline $1.9-[2.2$ & 0 & 14.5 & 1.8 & 0 & 1.8 & 1.8 & 0 & 80 & 0 \\
\hline $2.2-12.5$ & 2.4 & 29.3 & 2.4 & 0 & 2.4 & 0 & 2.4 & 58.5 & 2.4 \\
\hline $2.5-12.8$ & 0 & 55.6 & 11.1 & 11 & 11.1 & 0 & 0 & 11.1 & 0 \\
\hline $2.8-] 3.1$ & 0 & 60 & 0 & 20 & 0 & 0 & 20 & 0 & 0 \\
\hline $3.1-13.4$ & 0 & 100 & 0 & 0 & 0 & 0 & 0 & 0 & 0 \\
\hline $3.4-] 3.7$ & 0 & 25 & 50 & 0 & 0 & 0 & 0 & 25 & 0 \\
\hline
\end{tabular}

\section{TABLE III}

Pagurus brevidactylus. Percentage occupation of gastropod shell species by hermit-crab demographic groups.

\begin{tabular}{|c|c|c|c|c|c|c|c|c|}
\hline \multirow{2}{*}{ Gastropod species } & \multicolumn{2}{|c|}{ Total } & \multicolumn{2}{|c|}{$\mathbf{M}$} & \multicolumn{2}{|c|}{$\mathbf{F}$} & \multicolumn{2}{|c|}{ OF } \\
\hline & $N$ & $\%$ & $N$ & $\%$ & $N$ & $\%$ & $N$ & $\%$ \\
\hline Cerithium atratum (Born, 1778) & 41 & 22.2 & 27 & 65.9 & 8 & 19.5 & 6 & 14.6 \\
\hline Coralliophila aberrans (C.B. Adams, 1850) & 1 & 0.5 & 1 & 100.0 & 0 & 0.0 & 0 & 0.0 \\
\hline Gemophos auritulus (Link, 1807) & 5 & 2.7 & 5 & 100.0 & 0 & 0.0 & 0 & 0.0 \\
\hline Leucozonia nassa (Gmelin, 1791) & 2 & 1.1 & 2 & 100.0 & 0 & 0.0 & 0 & 0.0 \\
\hline Lithopoma tectum (Lightfoot, 1786) & 4 & 2.2 & 4 & 100.0 & 0 & 0.0 & 0 & 0.0 \\
\hline Modulus modulus (Linnaeus, 1758) & 1 & 0.5 & 0 & 0.0 & 1 & 100.0 & 0 & 0.0 \\
\hline Pisania pusio (Linnaeus, 1758) & 3 & 1.6 & 1 & 33.3 & 1 & 33.3 & 1 & 33.3 \\
\hline Trachypollia nodulosa (C.B. Adams, 1845) & 127 & 68.6 & 57 & 44.9 & 18 & 14.2 & 52 & 40.9 \\
\hline Tegula viridula (Gmelin, 1791) & 1 & 0.5 & 0 & 0.0 & 1 & 100.0 & 0 & 0.0 \\
\hline
\end{tabular}

( $N=$ number of individuals, $\mathrm{M}=$ males, $\mathrm{F}=$ females, $\mathrm{OF}=$ ovigerous females) 
TABLE IV

Paguristes tortugae. Percentage occupancy of gastropod shell species by hermit-crab size classes (Cat Cerithium atratum, Cpa Cymatium parthenopeum, Fbr Fusinus brasiliensis, Gau Gemophos auritulus, Lna Leucozonia nassa, Lte Lithopoma tectum, Ppu Pisania pusio, Ste Siratus tenuivaricosus, Sha Stramonita haemastoma, Tno Trachypollia nodulosa, Tvi Tegula viridula).

\begin{tabular}{|c|c|c|c|c|c|c|c|c|c|c|c|}
\hline & Cat & Cpa & Fbr & Gau & Lna & Lte & Ppu & Ste & Sha & Tno & Tvi \\
\hline $1.1-1.8$ & 33.3 & 0 & 0 & 0 & 0 & 0 & 0 & 0 & 0 & 66.7 & 0 \\
\hline $1.8-] 2.5$ & 25 & 0 & 0 & 0 & 0 & 0 & 0 & 0 & 0 & 75 & 0 \\
\hline $2.5-] 3.2$ & 60 & 0 & 0 & 20 & 0 & 10 & 0 & 0 & 0 & 5 & 5 \\
\hline $3.2-13.9$ & 46.2 & 0 & 1.8 & 19.2 & 3.8 & 19.2 & 11.5 & 0 & 0 & 0 & 0 \\
\hline $3.9-14.6$ & 0 & 0 & 2.4 & 73.5 & 2.9 & 2.9 & 20.6 & 0 & 0 & 0 & 0 \\
\hline $4.6-[5.3$ & 0 & 4.2 & 11.1 & 45.8 & 0 & 0 & 37.5 & 4.2 & 8.3 & 0 & 0 \\
\hline $5.3-16.0$ & 0 & 30 & 0 & 40 & 0 & 0 & 10 & 0 & 20 & 0 & 0 \\
\hline $6.0-16.7$ & 0 & 25 & 0 & 25 & 0 & 0 & 0 & 0 & 50 & 0 & 0 \\
\hline $6.7-17.4$ & 0 & 37.5 & 12.5 & 25 & 0 & 0 & 0 & 12.5 & 12.5 & 0 & 0 \\
\hline
\end{tabular}

Males of $P$. tortugae exploited a wider variety of shells than did non-ovigerous and ovigerous females, 10, six and five, respectively. Males occupied mainly G. auritulus shells (Chi-square test, $\left.X^{2}=5.8, P<0.05,31 \%\right) . G$. auritulus and C. atratum seemed to be important shell species for adult females, although not significantly so (Table V).

TABLE V

Paguristes tortugae. Percentage occupation of gastropod shell species by hermit-crab demographic groups.

\begin{tabular}{|c|c|c|c|c|c|c|c|c|}
\hline \multirow{2}{*}{ Gastropod species } & \multicolumn{2}{|c|}{ Total } & \multicolumn{2}{|c|}{$\mathbf{M}$} & \multicolumn{2}{|c|}{$\mathbf{F}$} & \multicolumn{2}{|c|}{ OF } \\
\hline & $N$ & $\%$ & $N$ & $\%$ & $N$ & $\%$ & $N$ & $\%$ \\
\hline Cerithium atratum (Born, 1778) & 30 & 20.3 & 8 & 11.9 & 7 & 25.9 & 15 & 27.8 \\
\hline Cymatium parthenopeum (Von Salis, 1793) & 8 & 5.4 & 6 & 9.0 & 0 & 0.0 & 2 & 3.7 \\
\hline Fusinus brasiliensis Grabau, 1904 & 1 & 0.7 & 1 & 1.5 & 0 & 0.0 & 0 & 0.0 \\
\hline Gemophos auritulus (Link, 1807) & 52 & 35.1 & 21 & 31.3 & 6 & 22.2 & 25 & 46.3 \\
\hline Leucozonia nassa (Gmelin, 1791) & 2 & 1.4 & 2 & 3.0 & 0 & 0.0 & 0 & 0.0 \\
\hline Lithopoma tectum (Lightfoot, 1786) & 8 & 5.4 & 6 & 9.0 & 2 & 7.4 & 0 & 0.0 \\
\hline Pisania pusio (Linnaeus, 1758) & 20 & 13.5 & 7 & 10.4 & 3 & 11.1 & 10 & 18.5 \\
\hline Siratus tenuivaricosus (Dautzenberg, 1927) & 2 & 1.4 & 2 & 3.0 & 0 & 0.0 & 0 & 0.0 \\
\hline Thais haemastoma (Linnaeus, 1767) & 7 & 4.7 & 7 & 10.4 & 0 & 0.0 & 0 & 0.0 \\
\hline Trachypollia nodulosa (C.B. Adams, 1845) & 17 & 11.5 & 7 & 10.4 & 8 & 29.6 & 2 & 8.7 \\
\hline Tegula viridula (Gmelin, 1791) & 1 & 0.7 & 0 & 0.0 & 1 & 3.7 & 0 & 0.0 \\
\hline
\end{tabular}

( $N=$ number of individuals, $\mathrm{M}=$ males, $\mathrm{F}=$ females, $\mathrm{OF}=$ ovigerous females $)$

For P. brevidactylus, hermit-crab weight (WW) and shell aperture length (SAL) were mostly related or were closely related to the occupation of shells of T. nodulosa and C. atratum. For P. tortugae, regression analyses were performed with $C$. atratum, G. auritulus and Pisania pusio shells, and the closest relationships recorded were hermit-crab cephalothoracic shield length (CSL), shell aperture length (SAL) and shell dry weight (SDW) (see Tables VI and VII for all relationships). 
TABLE VI

Pagurus brevidactylus. Regression equations for the relationships between hermit crabs and the two most-occupied shell species as a function of the hermit-crab size-frequency distribution.

\begin{tabular}{|c|c|c|c|c|}
\hline Shell species & $N$ & Relationship & $\ln Y=\ln a+b \ln X$ & $r$ \\
\hline \multirow[t]{6}{*}{ Trachypollia nodulosa } & 116 & CSL x SAL & $\operatorname{lnSAL}=0.50+0.47 \operatorname{lnSL}$ & $0.22 *$ \\
\hline & 116 & SL x SAW & $\operatorname{lnSAW}=0.10+0.37 \operatorname{lnSL}$ & 0.13 \\
\hline & 115 & SL x SDW & $\operatorname{lnSDW}=-0.42+0.82 \operatorname{lnSL}$ & 0.12 \\
\hline & 116 & WW x SAL & $\operatorname{lnSAL}=0.81+0.13 \ln W W$ & $0.25 *$ \\
\hline & 116 & WW x SAW & $\operatorname{lnSAW}=0.34+0.09 \ln W W$ & 0.11 \\
\hline & 115 & WW x SDW & $\operatorname{lnSDW}=0.19+0.28 \ln W W$ & 0.18 \\
\hline \multirow[t]{6}{*}{ Cerithium atratum } & 34 & SL x SAL & $\operatorname{lnSAL}=0.44+0.45 \operatorname{lnSL}$ & 0.25 \\
\hline & 34 & SL x SAW & $\operatorname{lnSAW}=0.22+0.59 \operatorname{lnSL}$ & 0.31 \\
\hline & 35 & SL x SDW & $\operatorname{lnSDW}=-0.47+0.95 \operatorname{lnSL}$ & 0.21 \\
\hline & 34 & WW x SAL & $\operatorname{lnSAL}=0.79+0.16 \ln W W$ & $0.36^{*}$ \\
\hline & 34 & WW x SAW & $\operatorname{lnSAW}=0.64+0.19 \ln W W$ & $0.35 *$ \\
\hline & 35 & WW x SDW & $\operatorname{lnSDW}=0.27+0.36 \ln W W$ & $0.32 *$ \\
\hline
\end{tabular}

( $N=$ number of individuals, $r=$ correlation coefficient, $\mathrm{CSL}=$ cephalothoracic shield length, $\mathrm{WW}=$ crab wet weight, $\mathrm{SAL}=$ shell aperture length, SAW= shell aperture width, SDW= shell dry weight, * significant values)

TABLE VII

Paguristes tortugae. Regression equations for the relationships between hermit-crabs and the four most-occupied shell species as a function of the hermit-crab size-frequency distribution.

\begin{tabular}{|c|c|c|c|c|}
\hline Shell species & $N$ & Relationship & $\ln Y=\ln a+b \ln X$ & $r$ \\
\hline \multirow[t]{6}{*}{ Trachypollia nodulosa } & 17 & SL x SAL & $\operatorname{lnSAL}=0.60+0.11 \ln S \mathrm{~L}$ & 0.02 \\
\hline & 17 & SL x SAW & $\operatorname{lnSAW}=0.17+0.17 \operatorname{lnSL}$ & 0.07 \\
\hline & 17 & SL x SDW & $\operatorname{lnSDW}=-0.44+0.95 \operatorname{lnSL}$ & 0.10 \\
\hline & 17 & WW x SAL & $\operatorname{lnSAL}=0.74+0.07 \ln W W$ & 0.09 \\
\hline & 17 & WW x SAW & $\operatorname{lnSAW}=0.31+0.06 \ln W W$ & 0.09 \\
\hline & 17 & WW x SDW & $\operatorname{lnSDW}=0.32+0.34 \ln W W$ & 0.15 \\
\hline \multirow[t]{6}{*}{ Pisania pusio } & 20 & SL x SAL & $\operatorname{lnSAL}=0.35+0.54 \operatorname{lnSL}$ & 0.36 \\
\hline & 20 & SL x SAW & $\operatorname{lnSAW}=0.61+0.47 \operatorname{lnSL}$ & $0.45^{*}$ \\
\hline & 20 & SL x SDW & $\operatorname{lnSDW}=-0.64+1.73 \operatorname{lnSL}$ & 0.33 \\
\hline & 20 & WW x SAL & $\operatorname{lnSAL}=1.00+0.18 \ln W W$ & 0.33 \\
\hline & 20 & WW x SAW & $\operatorname{lnSAW}=0.76+0.19 \ln W W$ & 0.38 \\
\hline & 20 & WW x SDW & $\operatorname{lnSDW}=0.67+0.50 \ln W W$ & 0.31 \\
\hline \multirow[t]{6}{*}{ Cerithium atratum } & 30 & SL x SAL & $\operatorname{lnSAL}=0.31+0.76 \operatorname{lnSL}$ & $0.56^{*}$ \\
\hline & 30 & SL x SAW & $\operatorname{lnSAW}=0.18+0.67 \operatorname{lnSL}$ & $0.39 *$ \\
\hline & 30 & SL x SDW & $\operatorname{lnSDW}=-0.70+1.57 \operatorname{lnSL}$ & $0.63^{*}$ \\
\hline & 30 & WW x SAL & $\operatorname{lnSAL}=0.84+0.19 \ln W W$ & $0.38^{*}$ \\
\hline & 30 & WW x SAW & $\operatorname{lnSAW}=0.66+0.17 \ln W W$ & 0.27 \\
\hline & 30 & WW x SDW & $\operatorname{lnSDW}=0.41+0.40 \ln W W$ & $0.41^{*}$ \\
\hline \multirow[t]{6}{*}{ Gemophos auritulus } & 52 & SL x SAL & $\operatorname{lnSAL}=0.35+0.54 \operatorname{lnSL}$ & $0.28^{*}$ \\
\hline & 52 & SL x SAW & $\operatorname{lnSAW}=0.61+0.47 \operatorname{lnSL}$ & 0.25 \\
\hline & 50 & SL x SDW & $\operatorname{lnSDW}=-0.14+0.60 \operatorname{lnSL}$ & 0.16 \\
\hline & 52 & WW x SAL & $\operatorname{lnSAL}=0.99+0.18 \ln W W$ & 0.23 \\
\hline & 52 & WW x SAW & $\operatorname{lnSAW}=0.78+0.20 \ln \mathrm{WW}$ & 0.25 \\
\hline & 50 & WW x SDW & $\operatorname{lnSDW}=0.63+0.22 \ln W W$ & 0.14 \\
\hline
\end{tabular}

( $N=$ number of individuals, $r=$ correlation coefficient, $\mathrm{CSL}=$ cephalothoracic shield length, $\mathrm{WW}=$ crab wet weight, $\mathrm{SAL}=$ shell aperture length, SAW= shell aperture width, SDW= shell dry weight, $*$ significant values) 


\section{DISCUSSION}

The studies available on the biology of Pagurus brevidactylus and Paguristes tortugae report that males are larger than females, reproductive activity remains intense over the annual cycle, and that crabs mature early (Negreiros-Fransozo and Hebling 1987, Negreiros-Fransozo et al. 1991, 1992, Mantelatto and Sousa 2000, Mantelatto et al. 2002, 2005, Iossi et al. 2005).

The trend toward a unimodal size-frequency distribution observed for both $P$. brevidactylus and P. tortugae has also been noted for most of the tropical and subtropical hermit crabs that have been studied, such as Paguristes erythrops (Biagi and Mantelatto 2006), Pagurus criniticornis (Mantelatto et al. 2007a), and Pagurus exilis (Mantelatto et al. 2007b). This tendency seems to be common for decapods in tropical and subtropical environments, which according to Díaz and Conde (1989) suggests a balance between continuous recruitment, with an even size-class distribution, and mortality rates.

The hermit crabs evaluated here are smaller than the species from soft-bottom communities, such as those observed by Hebling et al. (1994) on the southeastern Brazilian coast. In general, differences in body size suggest the existence of adaptations for exploiting rocky-bottom microhabitats, which provide shelter against predation as well as physical stresses, such as hydrodynamics, for different size scales (Meesters et al. 1991, Takada 1999, Bertness et al. 2001, Le Hir and Hily 2005).

The median size of $P$. tortugae was significantly larger than that of P. brevidactylus. According to Gherardi and Nardone (1997), this may result from evolution to reduce competition by partitioning the shell resource by size, with larger species preferring larger shells.

The median sizes recorded for $P$. brevidactylus and $P$. tortugae are similar to those reported by Mantelatto and Sousa (2000) and Mantelatto et al. (2005) from Anchieta Island, but smaller than those observed by Negreiros-Fransozo and Fransozo
(1992) for P. tortugae on rock bottoms of a sheltered continental beach in southeastern Brazil. Differences in the mean size of the same species in different areas have been recorded for other hermit crabs. Size could be constrained by shell availability, predation, diet, competition and parasitism (Manjón-Cabeza and García-Raso 1999), and also by differential hydrodynamic stresses (Le Hir and Hily 2005).

For both species, males reached larger median sizes and dominated the larger size classes. This difference between sexes is well documented for other hermit crabs, such as Diogenes nitidimanus from the Japanese coast (Asakura 1995) and for Clibanarius antillensis on the Mexican coast (Argüelles et al. 2009). This trait has also been observed for several species in Brazil (e.g., Paguristes calliopsis, Biagi et al. 2006; Pagurus exilis, Mantelatto et al. 2007b and Clibanarius vittatus, Sant'Anna et al. 2008, among others). Abrams (1988) noted that factors such as differential energy investment in growth and larger males are related to intra-specific competition, which could select for sexual dimorphism in body size in hermit crabs. Gherardi et al. (1989) suggested that the development of larger males is part of a strategy to maximize reproductive success and also to provide a selective advantage in accessing mating partners.

A peak of recruitment was observed in March and April 2010 for both species. Typically, coastal hermit crabs reproduce during the warm months, probably due to food availability and the acceleration of metamorphosis at higher temperatures (Negreiros-Fransozo and Fransozo 1992). However, Hebling and Negreiros-Fransozo (1983) observed that P. tortugae do not feed during the larval stages, and recruitment could continue throughout the year. The observed pattern could be part of a survival strategy, so that larvae of $P$. tortugae develop in synchrony with other planktonic species, which could decrease predation pressure. This suggestion is still speculative and requires experimental confirmation. 
The occurrence of ovigerous females of both species during almost the entire sampling period suggests continuous reproduction, as reported for some other hermit crabs (e.g., C. clibanarius, Varadarajan and Subramonian 1982; Calcinus tibicen, Mantelatto and Garcia 1999; and Pagurus criniticornis Mantelatto et al. 2007a, among others), which is a general pattern for most marine species in tropical and subtropical zones. In both species, the main season of frequency of ovigerous females extended from June 2010 through February 2011 , followed by an increase in the frequency of recruits in October 2010 and April and March 2011. Laboratory rearing studies estimated the mean duration of larval development at 28 days for P. brevidactylus (Negreiros-Fransozo and Hebling 1987) and 13 to 14 days for P. tortugae (Hebling and Negreiros-Fransozo 1983), which seems reasonable in view of the present field data for reproduction and recruitment.

The presence of small-sized ovigerous females, for both species, has been reported for other hermit crabs such as Pagurus annulipes at Nantucket Island, northeastern USA (Carlon and Ebersole 1995), and Paguristes tortugae (Mantelatto and Sousa 2000), Pagurus brevidactylus (Mantelatto et al. 2005) and P. criniticornis (Mantelatto et al. 2007a) in southeastern Brazil. According to Bertness (1981), hermit-crab reproduction could be constrained by shell availability, which could lead to a decrease in size at the onset of reproduction, and to inter- and intra-specific fighting. High adult mortality rate was mentioned by Stearns (1989) as one of the most important factors leading to early onset of sexual maturity, because individuals with lower survival rates needed to allocate more energy towards reproduction than towards growth, as observed by Yoshino et al. (2002) for Pagurus filholi.

Although both species showed continuous reproduction, few young individuals were collected during this investigation. Therefore, two hypotheses can be raised: 1) undersampling of juveniles, as proposed by Hartnoll and Bryant (1990), since the samples were taken by hand in a heterogeneous environment; 2) partitioning of habitat resources between juveniles and adults in order to reduce competition among demographic categories or to protect from predation, using algae and/or other biogenic substrates as shelter. As an example, Sargassum cymosum and Schizoporella unicornis are used by Calcinus tibicen (Fransozo and Mantelatto 1998), and Schizophorella unicornis are used by many brachyuran and anomuran decapods, as reported by Alves et al. (2013).

The fairly even sex ratios for both $P$. brevidactylus and $P$. tortugae are in agreement with the expected pattern of 1:1 described by Fischer theory (1930). However, some size classes deviated toward either males or females. Similar deviations have been reported for other hermit crabs and seem to be related to sexual selection, more-rapid development of males, and lower longevity of females (Bertness 1981, Abrams 1988, Mantelatto et al. 2005).

Populations of both $P$. brevidactylus and $P$. tortugae associated with the bryozoan Schizoporella unicornis (Alves et al. 2013) in southeastern Brazil also have a high predominance of adults. In this population of $P$. tortugae, the sex ratio of 1:2.6 was skewed toward females. All these reports reinforce the suggestion that habitat resources are partitioned between the juvenile and adult stages.

In these two species, the sex ratio in relation to size mostly followed the "anomalous" pattern described by Wenner (1972). In such a pattern, smaller size classes the sexes are fairly balanced, with a large excess of females in the intermediate size classes, and an excess of males in the largest ones. This pattern has been reported for many other species, e.g., Calcinus laevimanus by Wenner(1972), Calcinus lateens by Gherardi and McLaughlin (1994) and Clibanarius digueti by Harvey (1990).

The influence of the measured environmental parameters on the two species remains unclear. Only $P$. tortugae seemed to be affected by salinity 
range, during the period when the SACW normally intrudes on the southeastern Brazilian coast. Léo and Pires-Vanin (2006) noted that the SACW could affect population traits on both spatial and temporal scales. However, the possible association between P. tortugae and salinity variations requires complementary investigations to provide more-robust evidence concerning the importance of this water mass.

The two species showed an overlap in shell occupation, mainly for T. nodulosa and C. atratum shells. This overlap involved crabs with similar sizes, ranging from 1.0-2.5 mm CSL, but in different developmental stages. This situation is probably related to the shell shape, especially regarding the range of SAL and SDW, because these two species have smaller shells than the other shell species recorded. The limited variety of small shells likely accounts for the shared use of the shell by the two species, as previously reported by Mantelatto and Meireles (2004), which suggests that relatively few small gastropod shells are available locally.

Hermit crabs larger than $2.5 \mathrm{~mm}$ CSL occupied a wider variety of shells, particularly G. auritulus. Again, the shell richness seems to be the main reason for this differential occupation, since the variety of larger and heavier shells seems to be wider than that of small shells in this area, as also reported by Meireles et al. (2005).

In both hermit-crab species, the sexes showed different patterns of shell occupation, suggesting that this resource is partitioned, probably in order to reduce intra-specific competition. Similar differences in shell occupation have been recorded for Pagurus geminus and Clibanarius virescens on the Pacific coast of Japan (Imazu and Asakura 1994) and for Calcinus tibicen on the southeastern Brazilian coast (Mantelatto and Garcia 2000). Differential occupation as a function of sex seems to be related to the larger maximum sizes of males, who direct their energy budget to somatic growth, while females direct their energy to reproductive tasks, thus providing more shell options for males (Bertness 1980, 1981, Imazu and Asakura 1994).
A differential pattern of shell occupation was also recorded for ovigerous and non-ovigerous females of $P$. brevidactylus. A wide variety of shells were used by non-ovigerous females, while ovigerous females were mainly associated with $T$. nodulosa shells. This suggests that $T$. nodulosa shells were more available, as they were heavily exploited by males and non-ovigerous females of both hermitcrab species. Therefore, the preference of ovigerous females to occupy shells of $T$. nodulosa seems to form part of a strategy to avoid inter- and intra-specific shell competition. Mantelatto and Meireles (2004) suggested that the architecture of T. nodulosa shells could provide better protection against predators in comparison to shells of C. atratum.

For both hermit-crab species, the best-fit relationships were obtained for C. atratum. However, the correlation coefficients were practically not informative and even sometimes insignificant. Lancaster (1988) noted that hermit crabs in general use damaged shells, and even some with suboptimal sizes, which can be observed through the size relationship between the crab and its shell (Scully 1983), the crab's degree of retraction into the shell (Abrams 1978), and also by comparing the size of the occupied shells and the optimal size expected for these shells (Vance 1972, Bertness 1980).

In spite of their size difference, the two hermit-crab species overlapped in shell occupation, particularly for T. nodulosa and C. atratum. This indicates the existence of interaction between the crabs, and also with other species that use the same shells, as reported for $P$. brevidactylus and Pagurus criniticornis (Sant'Anna et al. 2012) on the southeastern coast. Interspecific interactions involving resource partitioning suggest that a regulatory process is probably part of the equilibrium strategy of these populations.

These populations of $P$. brevidactylus and $P$. tortugae have some features in common; they reach sexual maturity at small sizes, and the nearly yearround presence of young and ovigerous females, indicates continuous reproduction. These are 
common features of marine tropical and subtropical decapods, as a result of the relatively stable tropical environment. Shell occupancy seems to be the main constraint on the coexistence of these two species of hermit crabs.

\section{ACKNOWLEDGMENTS}

The authors are indebted to Janet $\mathrm{W}$. Reid, $\mathrm{PhD}$, for her constructive comments on early drafts of the manuscript and great help with the English language. Thanks are also due to colleagues of the LabBMar/UNITAU, who assisted in the dive sessions. The authors are grateful to Coordenação de Aperfeiçoamento de Pessoal de Nível Superior (CAPES) for the award of a Master's fellowship to the first author. Sampling was conducted in accordance with applicable state and federal laws.

\section{RESUMO}

Os principais objetivos deste estudo foram caracterizar a estrutura populacional e a ocupação de conchas de duas espécies simpátricas de ermitões, Pagurus brevidactylus e Paguristes tortugae. O estudo foi desenvolvido de março de 2010 a fevereiro de 2011, no sublitoral consolidado da Ilha das Couves, costa sudeste brasileira. Os espécimes foram coletados por meio de sessões de mergulho autônomo. Um total de 195 indivíduos de $P$. brevidactylus e 132 de $P$. tortugae foram examinados. Para ambas as populações foram registrados padrões de distribuição unimodal, que foram não normal para P. brevidactylus e normal para $P$. tortugae. O tamanho mediano para $P$. brevidactylus foi significativamente menor do que $P$. tortugae; para as duas espécies, machos foram significativamente maiores do que as fêmeas. Jovens e fêmeas ovígeras foram registrados na maior parte do período amostrado, assim como na maioria das classes de tamanho para ambas as espécies. Não foram verificadas diferenças significativas na proporção sexual 1:1 de ambas as populações, contudo desvios foram registrados em algumas classes de tamanho. Foram registradas sobreposições na utilização de conchas. Para $P$. brevidactylus e $P$. tortugae foram registradas características populacionais semelhantes; atingem a maturidade sexual em classes de tamanho iniciais, e a presença de jovens e fêmeas ovígeras em quase todo período de estudo sugere que tenham reprodução contínua. Essas interações interespecíficas envolvendo a partilha de recursos indica um processo de regulação, que provavelmente, está incluído na estratégia de equilíbrio dessas populações.

Palavras-chave: reprodução contínua, sublitoral consolidado, partilha de conchas, espécies simpátricas.

\section{REFERENCES}

ABRAMS PA. 1978. Shell selection and utilization in a terrestrial hermit crab, Coenobita compressus (H. Milne Edwards). Oecologia 34: 239-254.

ABRAMS PA. 1988. Sexual difference in resource use in hermit crabs; consequences and causes. In: Chelazzi $G$ and Vannini M (Eds), Behavioral adaptation to intertidal life (Nato Ai Series A, Life Sciences), vol 151. New York: Plenum Press, USA, p. 283-296.

Alves DFR, BARros-Alves SP, Lima DJM, CoBo VJ AND NEGREIROS-FrAnsozo ML. 2013. Brachyuran and anomuran crabs associated with Schizoporella unicornis (Ectoprocta, Cheilostomata) from southeastern Brazil. An Acad Bras Cienc 85: 245-256.

ArgüElles A, Álvarez F AND Alcaraz G. 2009. Shell architecture and its relation to shell occupation by the hermit crab Clibanarius antillensis under different wave action conditions. Sci Mar 73(4): 717-723.

ASAKURAA. 1995. Sexual differences in life history and resource utilization by the hermit crab. Ecology 76(7): 2295-2313.

BEGON M, HARPER JL AND TOWNSEND CR. 2007. Ecologia: De indivíduos a ecossistemas, Porto Alegre: Artmed,752 p.

BERTNESS MD. 1980. Shell preference and utilization patterns in littoral hermit crabs of the Bay of Panama. J Exp Mar Biol Ecol 48: 1-16.

BERTNESS MD. 1981. The influence of shell type on hermit crab growth rate and clutch size (Decapoda, Anomura). Crustaceana 40: 197-205.

BERTNESS MD, GAINES SD AND HAY ME. 2001. Marine community ecology, Sunderland:Sinauer Associates, Inc., USA, 550 p.

Biagi R AND Mantelatto FLM. 2006. Relative growth and sexual maturity of the hermit crab Paguristes erythrops (Anomura, Diogenidae) from South Atlantic. Hydrobiologia 559: 247-254.

Biagi R, Meireles AL and Mantelatto FLM. 2006. Bioecological aspects of the hermit crab Paguristes calliopsis (Crustacea, Diogenidae) from Anchieta Island, Brazil. An Acad Bras Cienc 78: 451-462.

CARLON DB AND EBERSOLE JP. 1995. Life-history variation among three temperate hermit crabs: the importance of size in reproductive strategies. Biol Bull 188: 329-337. 
Chase ID, Weissburg M AND Dewitt TH. 1988. The vacancy chain process: a new mechanism of resource distribution in animals with application to hermit crabs. Anim Behav 32: 131-142.

DíAz HAND CONDE JE. 1989. Population dynamics and life history of the mangrove crab Aratus pisonii (Brachyura, Grapsidae) in a marine environment. B Mar Sci 45(1): 148-163.

FISCHER RA. 1930. The genetical theory of natural selection. Clarendon Press, Oxford, New York.

Fransozo A AND MANTELATTO FLM. 1998. Population structure and reproductive period of the tropical hermit crab Calcinus tibicen (Decapoda: Diogenidae) in the region of Ubatuba, São Paulo, Brazil. J Crust Biol 18(4): 738-745.

GHERARDI F AND MCLAUGHLIN PA. 1994. Shallow-water hermit crabs from Mauritius and Rodrigues Islands, with the description of a new species of Calcinus. Raffles B Zool 42: 613-636.

GHERARDI F AND NARDONE F. 1997. The question of coexistence in hermit crabs: population ecology of a tropical intertidal assemblage. Crustaceana 70(5): 608-629.

GHERARDi F, TARDUCCI F AND MiChELI F. 1989. Energy maximization and foraging strategies in Potamon fluviatile (Decapoda, Brachyura). Freshwater Biol 22(2): 233-245.

HARTNOLL RG AND BRYANT AD. 1990. Size-frequency distribution in decapod Crustacea - the quick, the dead, and the cast-offs. J Crust Biol 10(1): 14-19.

HARVEY AW. 1990. Sexual differences in contemporary selection acting on size in the hermit crab Clibanarius digueti. Am Nat 136(3): 292-304.

Hebling NJ, Mantelatto FLM, Negreiros-Fransozo ML AND FRANSOZO A. 1994. Levantamento e distribuição de braquiúros e anomuros (Crustacea, Decapoda) dos sedimentos sublitorais da região da Ilha Anchieta. Bol Inst Pesca 27: 1-9.

Hebling NJ AND Negreiros-Fransozo ML. 1983. Desenvolvimento pós-embrionário de Paguristes tortugae Schmitt, 1933 (Decapoda, Diogenidae), em laboratório. Bolm Zool 6: 157-176.

HUTCHINSON GE. 1981. Introducción a la Ecología de Poblaciones, Barcelona: Blume, Spain, 492 p.

IMAZU M AND ASAKURA A. 1994. Distribution, reproduction and shell utilization patterns in three species of intertidal hermit crabs on a rocky shore on the Pacific coast of Japan. J Exp Mar Biol Ecol 184: 41-65.

Iossi C, BIAGI RAND MANTELATTO FLM. 2005. Egg production and shell relationship of the hermit crab Pagurus brevidactylus (Anomura: Paguridae) from southern Brazil. Anim Biol 55(2): 111-121.

LANCASTER I. 1988. Pagurus bernhardus (L.). An introduction to the natural history of hermit crabs. Field Studies 7: 189-238.

LE HIR ML AND HILY C. 2005. Macrofaunal diversity and habitat structure in intertidal boulder fields. Biodivers Conserv 14: 233-250.

LÉO FC AND PIRES-VANIN AMS. 2006. Benthic megafauna communities under the influence of the South Atlantic Central Water intrusion onto the Brazilian SE shelf: A comparison between an upwelling and a non-upwelling ecosystem. J Marine Syst 60: 268-284.
MANJÓN-CABEZA ME AND GARcía RASO JE. 1999. Shell utilization by the hermit crab Diogenes pugilator (Roux, 1829), Paguristes eremita (Linnaeus, 1767) and Pagurus forbesii Bell, 1845 (Crustacea: Decapoda: Anomura), in a shallow-water community from southern Spain. B Mar Sci 65(2): 391-405.

MANTELATTO FLM, ALARCON VF AND GARCIA RB. 2002. Egg production strategies of the tropical hermit crab Paguristes tortugae from Brazil. J Crust Biol 22(2): 390-397.

MANTELATTOFLM, CHRISTOFOLETTI RAAND VALENTI WC. 2005. Population structure and growth of the hermit crab Pagurus brevidactylus (Anomura: Paguridae) from the northern coast of São Paulo, Brazil. J Mar Biol Assoc UK 85: 127-128.

MANTElatto FLM, EsPósito DLA, TEROSSI M, BIAGI R AND MeIRELES AL. 2007b. Population features of the western Atlantic hermit crab Pagurus exilis (Anomura, Paguridae) in Brazil. Atlântica 29(2): 107-114.

MANTELATTO FLM, FARIA FCR, IOSSI CL AND BIAGI R. 2007a. Population and reproductive features of the western Atlantic hermit crab Pagurus criniticornis (Anomura, Paguridae) from Anchieta Island, southeastern Brazil. Iheringia, Ser Zool 97(3): 314-320.

MANTELATTO FLM AND GARCIA RB. 1999. Reproductive potential of the hermit crab Calcinus tibicen from Ubatuba, São Paulo, Brazil. J Crust Biol 19(2): 268-275.

MANTElatto FLM AND GARCIA RB. 2000. Shell utilization pattern of the hermit crab Calcinus tibicen from Southern Brazil. J Crust Biol 20(3): 460-467.

MANTELATTO FLM AND GARCiA RB. 2002. Hermit crab fauna from the infralitoral zone of Anchieta Island (Ubatuba, Brazil). In: Briones EE and Alvarez F (Eds), Modern Approaches to the study of Crustacea. New York: Kluwer Academic/Plenum, USA, p.137-144.

Mantelatto FLM AND MeIRELES AL. 2004. The importance of shell occupation and shell availability in the hermit crab Pagurus brevidactylus (Stimpson, 1859) (Paguridae) population from the southern Atlantic. B Mar Sci 75(1): 27-35.

MANTElatTo FLM AND Sousa LM. 2000. Population biology of the hermit crab Paguristes tortugae Schmitt, 1933 (Anomura, Diogenidae) from Anchieta Island, Ubatuba, Brazil. Nauplius 8(2): 185-193.

Meesters E, Knijn R, Willensen P, Pennartz R, Roebers G AND VAN SOEST RWM. 1991. Sub-rubble communities of Curacao and Bonaire coral reefs. Coral Reefs 10: 189-197.

Meireles AL, Biagi R and Mantelatto FLM. 2005. Gastropod shell availability as a potential resource for the hermit crab infralittoral fauna of Anchieta Island (SP), Brazil. Nauplius 11(2): 99-105.

Melo GAS. 1999. Manual de identificação dos Crustacea Decapoda do litoral Brasileiro: Anomura, Thalassinidea, Palinuridea e Astacidea, São Paulo: Editora Plêiade, 551 p.

Negreiros-Fransozo ML AND Fransozo A. 1992. Estrutura populacional e relação com a concha em Paguristes tortugae Schmitt, 1933 (Decapoda, Diogenidae) no litoral norte do estado de São Paulo, Brasil. Naturalia 17: 31-42. 
Negreiros-Fransozo ML, Fransozo A AND Hebling NJ. 1991. Estrutura populacional e determinação do tamanho da concha em 4 espécies de ermitões (Crustacea, Decapoda, Anomura) do litoral paulista. Biotemas 4(2): 135-148.

Negreiros-Fransozo ML, Fransozo A, MANTELATTO FLM, NAKAGAKI JM AND SPILBORGHS MCF. 1992. Fecundity of Paguristes tortugae Schmitt, 1933 (Crustacea, Decapoda, Anomura) in Ubatuba (SP) Brazil. Rev Brasil Biol 52(4): 547-553.

Negreiros-Fransozo ML AND HeBling NJ. 1987. Desenvolvimento pós-embrionário de Pagurus brevidactylus (Stimpson, 1858) (Decapoda, Paguridae), em laboratório. Rev Bras Zool 4(3): 181-193.

NuCCI PR AND Melo GA. 2007. Hermit crabs from Brazil. Family Paguridae (Crustacea: Decapoda: Paguroidea): Genus Pagurus. Zootaxa 1406: 47-59.

ORTON JH. 1920. Sea temperatures, breeding and distribution of marine animals. J Mar Biol Assoc UK 12: 339-366.

Rios E. 1994. Seashells of Brazil, Rio Grande: Editora da Fundação Universidade do Rio Grande, 492 p.

Rocha TCF, Dias-Brito D AND Milanelli JCC. 2010. Mapeamento da sensibilidade ambiental do litoral de Ubatuba-SP a vazamentos de petróleo. Rev Bras Cartogr 63(1): 157-170.

SANT'ANNA BS, Christofoletti RA, ZANGRANDE CM AND REIGADA ALD. 2008. Growth of the hermit crab Clibanarius vittatus (Bosc, 1802) (Crustacea, Anomura, Diogenidae) at São Vicente, São Paulo, Brazil. Braz Arch Biol Techn 51(3): 547-550.

SANT'ANNA BS, DOMINCIANO LCC, BUOZI SF AND TURRA A. 2012. Is shell partitioning between the hermit crabs Pagurus brevidactylus and Pagurus criniticornis explained by interference and/or exploitation competition? Mar Biol Res 8: 662-669.
SCULLY EP. 1983. The effects of shell availability on intraspecific competition in experimental populations of the hermit crab, Pagurus longicarpus Say. J Exp Mar Biol Ecol 71: 221-236.

SPIGHT TM. 1977. Availability and use of shells by intertidal hermit crabs. Biol Bull 152: 120-133.

STEARNS SC. 1989. Trade-offs in life history evolution. Funct Ecol 3: 259-268.

TAKADA Y. 1999. Influence of shade and number of boulder layers on mobile organisms on a warm temperate boulder shore. Mar Ecol Prog Ser 189: 171-179.

THORSON G. 1950. Reproductive and larval ecology of marine bottom invertebrates. Biol Rev 25(1): 1-45.

TURRA A AND LEITE FPP. 2001. Shell utilization patterns of a tropical rocky intertidal hermit crab assemblage: I. The case of Grande Beach. J Crust Biol 21(2): 393-406.

TURRA A AND LEITE FPP. 2004. Shell-size selection by intertidal sympatric hermit crabs. Mar Biol 145: 251-257.

VANCE RR. 1972. Competition and mechanism of coexistence in three sympatric species of intertidal hermit crabs. Ecology 53: 1062-1074.

VARADARAJAN S AND SUBRAMONIAM T. 1982. Reproduction of the continuously breeding tropical hermit crab Clibanarius clibanarius. Mar Ecol Prog Ser 8: 197-201.

WENNER AM. 1972. Sex ratio as a function of size in marine Crustacea. Am Nat 106(949): 321-350.

WILSON K AND HARDY ICW. 2002. Statistical analysis of sex ratios: an introduction. In: Hardy ICW (Ed), Sex ratios: Concepts and research methods. Cambridge: Cambridge University Press, United Kingdom, p. 48-92.

Yoshino K, Goshima S AND NAKAO S. 2002. Temporal reproductive patterns within a breeding season of the hermit crab Pagurus filholi: effects of crab size and shell species. Mar Biol 141: 1069-1075. 